\title{
огляди
}

\section{FREE RADICALS, REACTIVE OXYGEN SPECIES, OXIDATIVE STRESSES AND THEIR CLASSIFICATIONS}

\author{
V. I. LUSHCHAK \\ Vasyl Stefanyk Precarpathian National University, Ivano-Frankivsk, Ukraine; \\ e-mail: lushchak@pu.if.ua
}

The phrases "free radicals" and "reactive oxygen species" (ROS) are frequently used interchangeably although this is not always correct. This article gives a brief description of two mentioned oxygen forms. During the first two-three decades after ROS discovery in biological systems (1950-1970 years) they were considered only as damaging agents, but later their involvement in organism protection and regulation of the expression of certain genes was found. The physiological state of increased steady-state ROS level along with certain physiological effects has been called oxidative stress. This paper describes ROS homeostasis and provides several classifications of oxidative stresses. The latter are based on time-course and intensity principles. Therefore distinguishing between acute and chronic stresses on the basis of the dynamics, and the basal oxidative stress, low intensity oxidative stress, strong oxidative stress, and finally a very strong oxidative stress based on the intensity of the action of the inductor of the stress are described. Potential areas of research include the development of this field with complex classification of oxidative stresses, an accurate identification of cellular targets of ROS action, determination of intracellular spatial and temporal distribution of ROS and their effects, deciphering the molecular mechanisms responsible for cell response to ROS attacks, and their participation in the normal cellular functions, i.e. cellular homeostasis and its regulation.

Key words: cell function, homeostasis, cellular targets, classifications of oxidative stresses.

I n the early 1900's M. Gomberg, native from Elisavetgrad province of the Russian Empire (now the Kirovohrad region of Ukraine), whose family immigrated to Chicago, USA, escaping the pogroms of 1884, related to the murder of Tsar Alexander II, discovered free radicals [1]. In 1930, German scientist L. Michaelis suggested that free radicals were involved in all chemical reactions [2]. Although generally this assumption was wrong, it attracted attention of researchers to this problem. High reactivity of free radicals initially regarded as such, did not assume they exist in living organisms. But in the early 1950's, free radicals were found in living organisms, and almost immediately were related to various diseases [3] and aging $[4,5]$. For a long time free radicals were believed to be only negatively affecting the living organisms. If this was true, then it was obvious that living organisms should possess systems to protect against free radicals. And if existence and role of low molecular mass antioxidants such as tocopherol or ascorbic acid were known at the time, information on the presence of enzymes dealing with free radicals directly as substrates appeared only in the late 1960's. So, J. McCord and I. Fridovich described a new enzymatic activity of the protein long known as erythrocuprein (hemocuprein) [6]. This protein was found to catalyze dismutation of the superoxide anion radical $\left(\mathrm{O}_{2}{ }^{-}\right)$ due to which it was called superoxide dismutase (SOD). Later, SOD was found in virtually all aerobic organisms and, furthermore, its activity was regulated at transcriptional level, and a small increase in the level of reactive oxygen species (ROS) increased its activity. It should be noted that ROS at high levels inactivate antioxidant enzymes. In 1970, it was found that organisms generate ROS in controlled manner, particularly in leukocytes certain components generate $\mathrm{O}_{2}^{--}$and other reactive species for protection against microorganisms and parasites [7-11]. Finally, in several well known regulatory pathways ROS were found to operate as mediators [12-19]. In addition, in 1990 it became clear 
that ROS were not only harmful byproducts of life, but also were its indispensable components. Moreover, organisms were able to generate ROS in finely controlled manner in certain amounts and locations. Now we can talk about ROS homeostasis, although in this area, the term is virtually not used.

Despite the fact, that the processes related to ROS homeostasis have been studied very intensively for more than half a century, we cannot say that we have a clear understanding of their role in the processes which they participate in. Moreover, up to now there are even terminological differences. Therefore, in this article I will characterize free radicals and ROS, describe their interconversion, and, finally, give the definition of oxidative stresses and their classifications.

\section{Free radicals and reactive oxygen species}

Molecular oxygen by attaching four electrons and four protons is converted into water. In addition to this virtually simultaneous four-electron reduction of molecular oxygen, there is another - one-electron successive reduction (Fig. 1). The intermediates include superoxide anion radical $\left(\mathrm{O}_{2}{ }^{-}\right)$, hydrogen peroxide $\left(\mathrm{H}_{2} \mathrm{O}_{2}\right)$, and hydroxyl radical (HO). And finally attachment of another electron and proton to $\mathrm{HO}{ }^{\bullet}$ results in the formation of water molecule, thus completing reduction of oxygen molecules to water. From the group of partially reduced oxygen forms only $\mathrm{O}_{2}{ }^{-}$and $\mathrm{HO}^{-}$are free radicals, whereas $\mathrm{H}_{2} \mathrm{O}_{2}$ is not free radical. However, $\mathrm{O}_{2}{ }^{-}, \mathrm{H}_{2} \mathrm{O}_{2}$ and $\mathrm{HO}^{-}$not being all free radicals, are characterized by higher activity than molecular oxygen, due to which they were called collectively reactive oxygen species (ROS). It is important to note that often erroneously all forms of partially reduced oxygen molecules or particles are called free radicals ignoring the fact that $\mathrm{H}_{2} \mathrm{O}_{2}$ is not a free radical.

In biological systems, transformation of ROS occurs spontaneously with involvement of low-molecular mass electron donors (upper part of Fig. 1). However, in living organisms there are enzymatic systems significantly accelerating one-electron ROS conversion. Above mentioned enzyme superoxide dismutase accelerates $\mathrm{O}_{2}^{--}$dismutation transforming it into hydrogen peroxide and molecular oxygen (Fig. 1). To date, enzymatic systems protecting against hydroxyl radical have not been described (apparently they do not exist because of high HO* reactivity), and prevention of its formation seems is the only protective mechanism. That is why it is necessary to keep $\mathrm{H}_{2} \mathrm{O}_{2}$ level very low. Elimination of $\mathrm{H}_{2} \mathrm{O}_{2}$ is provided by different peroxidases. Catalase dismutates $\mathrm{H}_{2} \mathrm{O}_{2}$ to water and molecular oxygen, whereas other peroxidases use as a cofactor various organic compounds capable of donating electrons to $\mathrm{H}_{2} \mathrm{O}_{2}$. Here, I will focus only on the glutathionedependent peroxidases (GPx). They reduce hydrogen peroxide along with many other peroxides, in particular those of lipids, to alcohols and water. This results in simultaneous oxidation of glutathione. Reduction of oxidized glutathione is provided by enzyme glutathione reductase, which for these purposes uses NADPH. And finally, maintaining of NADPH level is provided by a group of enzymes dehydrogenases, among which the main role is ascribed to glucose-6-phosphate dehydrogenase, a key enzyme of the pentose phosphate shunt (Fig. 1). Thus, we have consistently followed the relationship between the operation of antioxidant defense system and metabolism of carbohydrates.

It is worthy to underline that the activity of antioxidant enzymes is precisely regulated by the cell: on the one hand, it is enhanced at low ROS level increase due to upregulation of their expression, whereas on the other hand it is decreased at substantial ROS level increase due to inactivation by ROS.

\section{Oxidative stresses and their classifications}

Normally, in a living cell there is a fine balance between the intensity of ROS formation and degradation. This balance provides a certain steady-state ROS level, i.e. a system exists in a dynamic equilibrium. However, due to certain processes, this balance can be disturbed, leading to an increase in the steady-state ROS level. In 1985, a German researcher $H$. Sies first introduced the definition of oxidative stress: "Oxidative stress" as results from imbalance in this pro-oxidant-antioxidant equilibrium in favor of the pro-oxidants" [20]. Since then, 30 years have passed and we have substantially improved our knowledge about oxidative stress. Therefore, I propose here one more accurate and updated definition: "Oxidative stress is a transient or persistent increase of steady-state ROS level, disturbing cellular core and signaling pathways, including ROS-based ones, leading to oxidative modification of cellular constituents which, if not counterbalanced, may culminate in cell death via necrosis or apoptosis”. This 


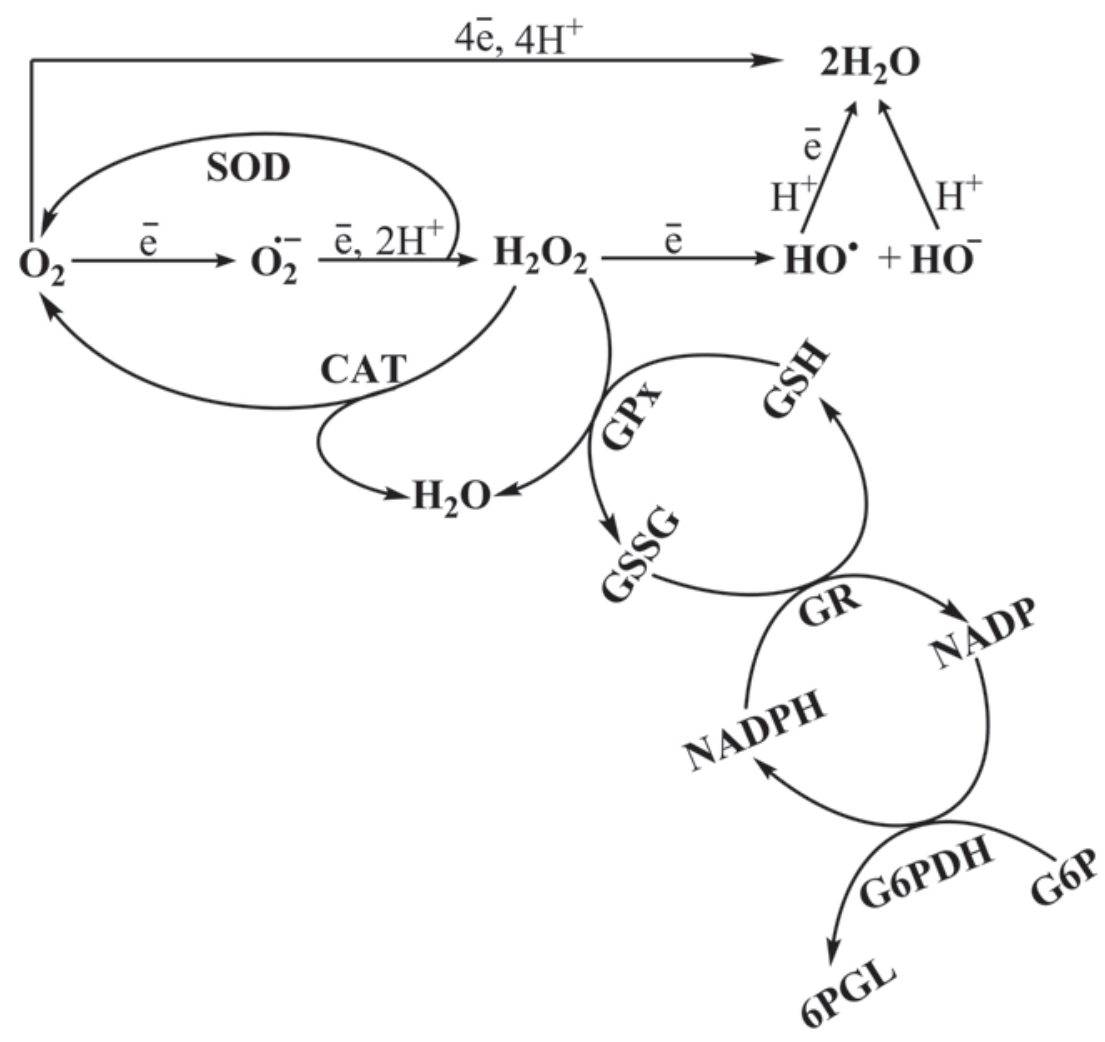

Fig. 1. Four-and consistent one-electron reduction of molecular oxygen and antioxidant enzymes of the first and second lines. Addition of one electron to oxygen molecule leads to the formation of superoxide anion radical $\left(\mathrm{O}_{2}^{--}\right)$. Further addition of one more electron to $\mathrm{O}_{2}^{--}$leads to the formation of hydrogen peroxide $\left(\mathrm{H}_{2} \mathrm{O}_{2}\right)$, which is not a radical. One-electron $\mathrm{H}_{2} \mathrm{O}_{2}$ reduction leads to the formation of the hydroxyl radical (HO) and hydroxyl anion. Finally, addition of one more electron and proton to $\mathrm{HO}^{*}$ results in water molecule formation. Two above-mentioned partially reduced oxygen species, namely $\mathrm{O}_{2}{ }^{--}$and $\mathrm{HO}$ are free radicals, but $\mathrm{H}_{2} \mathrm{O}_{2}$ is not. All together forms of partially reduced oxygen $\left(\mathrm{O}_{2}{ }^{-}, \mathrm{H}_{2} \mathrm{O}_{2}\right.$, and $\left.\mathrm{HO} \mathrm{O}^{*}\right)$ have higher chemical reactivity than molecular oxygen, due to which they were collectively named as "reactive oxygen species" (ROS). Transformation of $\mathrm{O}_{2}^{-}$to $\mathrm{H}_{2} \mathrm{O}_{2}$ is significantly accelerated by certain enzymes, called primary antioxidant enzymes. The first enzyme in this chain is called superoxide dismutase (SOD) and it catalyzes a redox reaction of disproportionation of two $\mathrm{O}_{2}^{--}$molecules resulting in formation of molecular oxygen and hydrogen peroxide. The next component in the chain of one-electron $\mathrm{O}_{2}$ reduction of $\mathrm{ROS}, \mathrm{H}_{2} \mathrm{O}_{2}$ may be converted to less harmful species by several enzymes of a large group called peroxidases. Catalase dismutates $\mathrm{H}_{2} \mathrm{O}_{2}$ to molecular oxygen and water, while glutathione dependent peroxidases (GPx) using glutathione as a cofactor reduce it to water. Since currently there is no reliable information on the existence of specific enzyme systems dealing with hydroxyl radicals, it is generally accepted that prevention of its formation is the best way to combat it. Abbreviations: $C A T$ - catalase; GPx-glutathione dependent peroxidase; GR - glutathione reductase; G6PDH - glucose6-phosphate dehydrogenase; G6P-glucose-6-phosphate; 6PGL-6-phosphoglucolactone; GSH and GSSGreduced and oxidized forms of glutathione; NADP and NADPH - oxidized and reduced forms of nicotinamide adenine dinucleotide phosphate; SOD - superoxide dismutase

definition emphasizes the dynamic nature of ROS level and their impact on basic and regulatory cellular processes.

Though the oxidative stress has been investigated for more than three decades, the classification system has appeared only recently. This is not surprising, because this phenomenon is very complicated due to many reasons. Having been actively working on oxidative stress for more than 20 years, our group always felt the need for such a classification. Few years ago, I proposed several approaches to develop such classification [16-19, 21], which has 
already been partially recognized in particular by such pioneer in the field of redox biology as H. Sies [22]. Clearly realizing impossibility to propose ideal classification (moreover universal), I put two complementary principles in the basis of classification: dynamic response (temporal classification) and the influence of the stress inductor/s of different intensity (intensively based classification). Such approach resulted in two groups of classifications based on the dynamics of the stress and on the intensity of the stress (Fig. 2). Next, the mentioned classifications are considered in detail.

In the cell, under non-stressed conditions certain steady-state ROS level exists, fluctuating within a certain range in accordance with the theory of homeostasis. But at certain point due to action of some external or internal factors ROS level rises and exceeds normal range causing a cascade of cell responses. If the protective antioxidant potential of the cell is high enough and the cell is well provided with energy and plastic resources, the level of ROS in seconds, minutes or hours returns to the initial corridor (Fig. 2). In this scenario, we clearly see the development of short time or acute oxidative stress
[18]. But often there is a situation where the cell cannot return ROS level into initial corridor and it remains slightly higher than the control: it may include the original corridor or stabilize at slightly higher values of steady-state concentrations of ROS. Such stress can last in hours, days and months. This may result in significant reorganization of cell status, adapting to new conditions. In particular, this can result in strengthening of the antioxidant system. The latter can play a significant role in cell protection against deleterious ROS effects. Such prolonged stress is called "chronic oxidative stress" $[18,19]$. The situation when steady-state ROS level is stabilized in the corridor, above the original and not attached to it is called "quasi-stationary level". Summarizing, the transient (short-time) increase in steady-state ROS concentrations is called acute oxidative stress, whereas prolonged sustained enhanced ROS level is called chronic oxidative stress.

The second proposed classification of oxidative stresses is based on the intensity of oxidative stress state. Figure 3 shows development of oxidative stress depending on the dose/concentration of stress inducer. Curve 1 here shows the level of ROS-

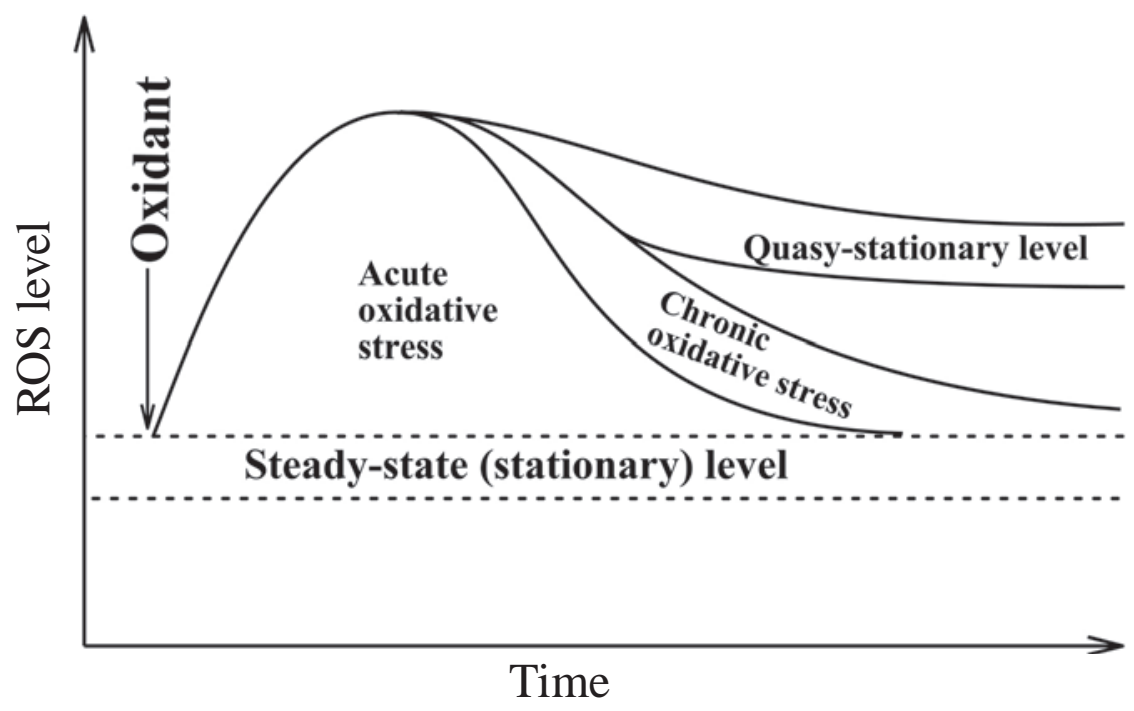

Fig. 2. Schematic presentation of the time-course based classification of oxidative stresses. Usually, the stationary ROS concentration is maintained within a certain range and oscillates like other parameters in the body according to homeostasis theory. However, under certain circumstances, ROS concentration may leave this corridor due to increased generation or decreased elimination. Conditions when ROS level is increased for a short time period with certain functional consequences has been called "acute oxidative stress", while a prolonged increase in ROS levels accompanied by such consequences is called "chronic oxidative stress". In some cases, the level of ROS is not returned into the original corridor or close to it and may stabilize at a higher steady-state level, called quasi-stationary one. Both acute and chronic oxidative stresses may have different effects on living organisms and cause more or less significant damage to the cells and, if the system is unable to regain control, it can lead to cell death from apoptosis or necrosis 
modified (oxidized lipids, proteins, etc.) parameter (ROMP), and the curve 2 - the level of ROS-inducible and ROS-regulated/ROS-sensitive parameter (ROSISP) of the stress (activity of antioxidant enzymes or survival of organisms/cells). Zone I, where oxidative stress cannot be registered by conventional methods, is called basal oxidative stress (BOS). In zone II called low intensity oxidative stress (LOS), both parameters demonstrate an increase relatively to the initial level, but with different patterns: curve 1 gradually increases, whereas curve 2 grows to a certain maximum and further with increased ROS dose/concentration returns to the initial level. At cross of ROSISP and ZEP, ROSISP gets the same value as without oxidative stress induction (zero point) or in zone I. However, at transition to zone III it goes down, whereas ROMP continues to grow and this zone III is called intermediate intensity oxidative stress (IOS). Finally, in zone IV, called high intensity oxidative stress (HOS), ROMP approaches maximum, whereas ROSISP approaches a zero or certain asymptote. Discrimination between zones III and IV is a complicated task. However, some formal tools may be applied here. It is possible to use ideas on cooperative interaction between ligand and some binding substances. In this case, so-called Hill equation may be applied to curve 1 [23, 24]. Maximum "binding" may be calculated using experimental data. After that, one may suggest, that the border between zones III and IV would be at the point, where ROMP consists of $90 \%$ of maximum value. It is clear, that the proposed approach is formal, but it can help to discriminate between IOS and HOS zones.

Recognizing the difficulties of practical application of the described above classifications of oxidative stresses as the function of their intensity, I offer its significantly simplified version, which is easier to use in practice than the previous one. In this case, zone I is ignored since experimentally it is virtually impossible to estimate, and zone II should be called "low intensity oxidative stress" (LOS). Next, zones III and IV are combined into one, called "strong oxidative stress" (SOS). While the latter classification theoretically seems fairly simple, its practical appli-

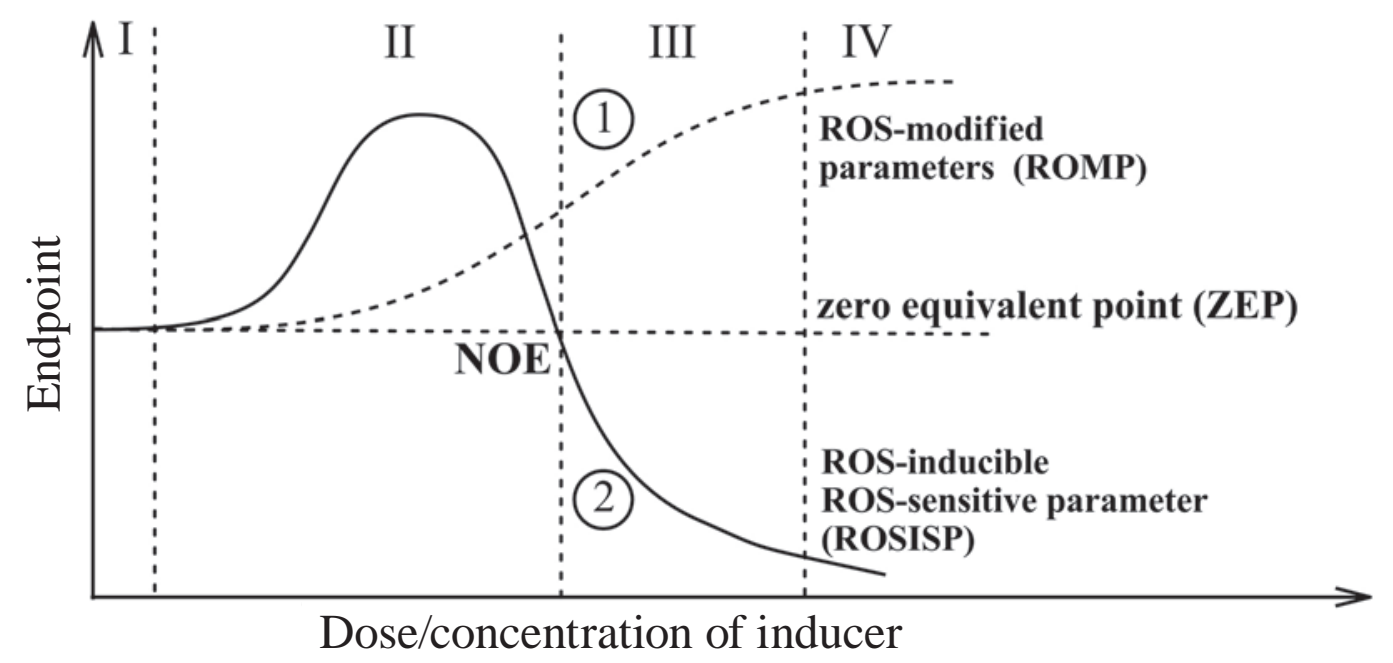

Fig. 3. Schematic presentation of the intensity-based classification of oxidative stresses. Curve 1 indicates the level of ROS-modified cell component/parameter (ROMP), whereas curve 2 shows ROS-inducible ROSsensitive parameter (ROSISP), such as activity of antioxidant enzyme or cell survival. In fact, the curves 1 and 2 show the relationship between the dose/concentration of the oxidative stress inducer and the parameters typically used to characterize the stress and which can be experimentally measured. Zone I-basal oxidative stress (BOS), where there is no observable effects that cannot be registered due to the very low intensity of oxidative stress; Zone II - low intensity oxidative stress (LOS) with slightly increased level of ROS-modified molecules and enhanced activity of antioxidant enzymes or cell survival in response to enhanced ROS level; Zone III - strong oxidative stress (SOS); and Zone IV-very strong oxidative stress (VOS), where the values of the recorded parameters reach nearly maximum/minimum values. Abbreviations: NOE - no observable effect point; ZEP-zero equivalent point - the level of components of interest corresponds to the initial (basic) level in the absence of inducer of oxidative stress. (Modified from [18, 19]) 
cation may also face problems, some of which are listed below.

\section{Practical use of and prospects for the classification}

As mentioned above, theoretically well looking classification systems are not easily applied practically due to several reasons. The first is related to the very high complexity of living organisms and freeradical processes. This leads to poor predictability and reproducibility of the experimental results. Apparently, the use of simple cellular models may be helpful here to some extent. However, this may be the way out only partially, because we are mostly interested in ourselves, in humans. In the worst case, we have bigger interests in closest to us vertebrate organisms especially mammals. With multicellular organisms, different sensitivity to inducers of stress, reaching different organs by the inducers and different organ specificity response seriously complicate studies in the field.

Careful and correct selection of indicators that are used to characterize the state of oxidative stress is the second major problem. Numerous experimental data suggest that different oxidative stress markers have different sensitivity to dose/concentration of inducer. It seems necessary to analyze all possible indicators, using the criteria of appropriateness and adequacy. Theoretical knowledge and experience of the reseacher then become paramount here. Apparently, a simple weighted number of parameters that fall into one or another zone may help to draw conclusions about the development of certain types of the stress.

Development of an integrated and universal system of classification of oxidative stresses is the third and probably the most difficult problem. The need for such work clearly comes from an understanding of artificial assumptions, to some extent, used for classifications and the awareness of the need for further development of research in the field of ROS homeostasis. Ideally, such a system should include the spatiotemporal and the dose/concentration indices. Clear identification of ROS targets, involved coordinating regulatory pathways and the maximum number of physiological responses require the use of multiple approaches with mathematical classification and generalization. But this is a goal for the next generation of researchers. Classifications provided in this article can serve as the first and most likely preliminary step in the development of a universal system of classification of oxidative stresses. And even though, more or less good classifications will have many limitations, they will be useful for both fundamental science and applied research.

\section{ВІЛЬНІ РАДИКАЛИ, АКТИВНІ ФОРМИ КИСНЮ, ОКСИДАТИВНІ СТРЕСИ ТА ЇХ КЛАСИФІКАЦІЯ}

\section{B. І. Лущ̧ак}

Прикарпатський національний університет імені Василя Стефаника, Івано-Франківськ, Україна; e-mail: lushchak@pu.if.ua

Словосполучення «вільні радикали» і «активні форми кисню» (АФК) часто використовуються як взаємозамінні, хоча це не завжди вірно. У цій статті коротко описуються ці форми кисню. Протягом перших двох-трьох десятиліть після відкриття АФК у біологічних системах (1950-1970 роки) вони розглядалися тільки як пошкоджуючі агенти, але пізніше була описана їхня захисна роль і регуляція експресії певних генів. Фізіологічний стан, за якого стаціонарний рівень АФК підвищений, разом із деякими фізіологічними ефектами, одержав назву оксидативного стресу. У цій статті описано гомеостаз АФК і подано кілька систем класифікації оксидативних стресів. Останні грунтуються на принципах динаміки та інтенсивності. Так, часова класифікація описує гострий та хронічний стреси, а класифікація за інтенсивністю включає базальний оксидативний стрес, легкий оксидативний стрес, сильний оксидативний стрес, i, нарешті, дуже сильний оксидативний стрес. Подальші дослідження в цій галузі будуть спрямовані на розробку комплексної класифікації оксидативних стресів, точне визначення клітинних мішеней дії АФК, визначення внутрішньоклітинного просторового і часового розподілів АФК та наслідків їх дії, розшифровку молекулярних механізмів, які відповідають за клітинну відповідь на дію АФК, а також їх участь у нормальних клітинних функціях, тобто клітинному гомеостазі та його регуляції.

К л ю ч о в і с л о в а: клітинні функції, гомеостаз, клітинні мішені, класифікація оксидативних стресів. 


\section{СВОБОДНЫЕ РАДИКАЛЫ, АКТИВНЫЕ ФОРМЫ КИСЛОРОДА, ОКСИДАТИВНЫЕ СТРЕССЫ И ИХ КЛАССИФИКАЦИЯ}

\section{В. И. Лущчак}

Прикарпатский национальный университет имени Васыля Стефаника, Ивано-Франковск, Украина; e-mail: lushchak@pu.if.ua

Словосочетание «свободные радикалы» и «активные формы кислорода» (АФК) часто используются как взаимозаменяемые, хотя это не всегда верно. В этой статье кратко описываются две упомянутые формы кислорода. В течение первых двух-трех десятилетий после открытия АФК в биологических системах (1950-1970 годы) они рассматривались только как повреждающие агенты, но позже была описана их защитная роль и регуляция экспрессии определенных генов. Физиологическое состояние, при котором увеличивается стационарный уровень АФК вместе с некоторыми физиологическими эффектами, получило название оксидативного стресса. В работе описан гомеостаз АФК и представлены несколько систем классификации оксидативного стресса. Последние базируются на принципах динамики и интенсивности. Так, временная классификация описывает острый и хронический стрессы, а классификация по интенсивности включает базальный оксидативный стресс, легкий оксидативный стресс, сильный оксидативный стресс, и, наконец, очень сильный оксидативный стресс. Дальнейшие исследования в этой области будут направлены на разработку комплексной классификации оксидативного стресса, точное определение клеточных мишеней действия АФК, определения внутриклеточного пространственного и временного распределений АФК и последствий их действия, расшифровку молекулярных механизмов, которые отвечают за клеточный ответ на действие АФК, а также их участие в нормальных клеточных функциях, т.е. клеточном гомеостазе и его регуляции.

Ключевы е слова: клеточные функции, гомеостаз, клеточные мишени, классификация оксидативных стрессов.

\section{References}

1. Gomberg M. An instance of trivalent carbon: triphenylmethyl. J. Am. Chem. Soc. 1900; 22(1): 757-771.

2. Michaelis L. Free radicals as intermediate steps of oxidation-reduction. Cold Spring Harb. Symp. Quant. Biol. 1939; 7: 33-49.

3. Gerschman R., Gilbert D. L., Nye S.W., Dwyer P., Fenn W. O. Oxygen poisoning and X-irradiation: a mechanism in common. Science. 1954; 119(3097): 623-626.

4. Harman D. Aging: a theory based on free radical and radiation chemistry. J. Gerontol. 1956; 11(3): 298-300.

5. Harman D. Origin and evolution of the free radical theory of aging: a brief personal history, 1954-2009. Biogerontology. 2009; 10(6): 773781.

6. McCord J. M., Fridovich I. Superoxide dismutase. An enzymic function for erythrocuprein (hemocuprein). J. Biol. Chem. 1969; 244(22): 6049-6055.

7. Babior B. M. The respiratory burst of phagocytes. J. Clin. Invest. 1984; 73(3): 599-601.

8. Babior B. M., Curnutte J. T., Kipnes R. S. Biological defense mechanisms. Evidence for the participation of superoxide in bacterial killing by xanthine oxidase. J. Lab. Clin. Med. 1975; 85(2): 235-244.

9. Babior B. M., Kipnes R. S., Curnutte J. T. Biological defense mechanisms. The production by leukocytes of superoxide, a potential bactericidal agent. J. Clin. Invest. 1973; 52(3): 741-744.

10. Rossi F., Della Bianca V., de Togni P. Mechanisms and functions of the oxygen radicals producing respiration of phagocytes. Comp. Immunol. Microbiol. Infect. Dis. 1985; 8(2): 187-204.

11. Britigan B. E., Cohen M. S., Rosen G. M. Detection of the production of oxygen-centered free radicals by human neutrophils using spin trapping techniques: a critical perspective. J. Leukoc. Biol. 1987; 41(4): 349-362.

12. Christman M. F., Morgan R. W., Jacobson F. S., Ames B. N. Positive control of a regulon for defenses against oxidative stress and some heatshock proteins in Salmonella typhimurium. Cell 1985; 41(3): 753-762. 
13. Morgan R. W., Christman M. F., Jacobson F. S., Storz G., Ames B. N. Hydrogen peroxideinducible proteins in Salmonella typhimurium overlap with heat shock and other stress proteins. Proc. Natl. Acad. Sci. USA. 1986; 83(21): 80598063.

14. Tartaglia L. A., Storz G., Ames B. N. Identification and molecular analysis of oxyRregulated promoters important for the bacterial adaptation to oxidative stress. J. Mol. Biol. 1989; 210(4): 709-719.

15. Scandalios J. G. Oxidative stress: molecular perception and transduction of signals triggering antioxidant gene defenses. Braz. J. Med. Biol. Res. 2005; 38(7): 995-1014.

16. Lushchak V. I. Adaptive response to oxidative stress: Bacteria, fungi, plants and animals. Comp. Biochem. Physiol. C. Toxicol. Pharmacol. 2011; 153(2): 175-190.

17. Lushchak V. I. Environmentally induced oxidative stress in aquatic animals. Aquat. Toxicol. 2011; 101(1): 13-30.

18. Lushchak V. I. Free radicals, reactive oxygen species, oxidative stress and its classification. Chem. Biol. Interact. 2014; 224C: 164-175.
19. Lushchak V. I. Classification of oxidative stress based on its intensity. EXCLI J. 2014; 13: 922937.

20. Sies H. Oxidative stress: introductory remarks / Sies H. Oxidative Stress: Academic Press, 1985; P. 1-8.

21. Lushchak V. I. Glutathione homeostasis and functions: potential targets for medical interventions. J. Amino Acids. 2012; 2012: 736837. 26 p.

22. Sies H. Oxidative stress: a concept in redox biology and medicine. Redox. Biol. 2015; 4: 180183.

23. Goutelle S., Maurin M., Rougier F., Barbaut X., Bourguignon L., Ducher M., and Maire P. The Hill equation: a review of its capabilities in pharmacological modelling. Fundam. Clin. Pharmacol. 2008; 22(6): 633-648.

24. Frank S. A. Input-output relations in biological systems: measurement, information and the Hill equation. Biol. Direct. 2013; 8: 31.

Received 10.08.2015 